\title{
Introduction and Impact of Integrated Teaching Learning Method for First Professional Medical Students
}

\author{
Gulab Kanwar ${ }^{1}$, Monika Shekhawat $^{2 *}$, Neeraj Saxena ${ }^{3}$, Mahesh Chandra Mehra ${ }^{4}$ \\ ${ }^{1,2}$ Professor and Head, Department of Biochemistry, GMC, Kota (Rajasthan), India \\ ${ }^{3,4}$ PG Residents, Department of Biochemistry, GMC, Kota (Rajasthan), India
}

\begin{abstract}
Background: Integrated Teaching refers to a way of connecting skills and knowledge from multiple sources and experiences or applying skills and practice in various settings. It simply means bridging connection between academic knowledge and practicals. Integrated teaching offers many advantages and may be a key factor in the delivery of an effective educational programme.

Aims and objectives: Introduction of integrated teaching learning in First MBBS, to study the impact of Integrated teaching learning and to compare integrated teaching learning with traditional learning.

Method: Present study was carried out with First yr. MBBS Batch 2014-15 at Govt. Medical College, Kota. Duration of study was from March to August 2015. Traditional teaching was done on topics Thyroid and Jaundice. Pre test (50 MCQs) was taken. Integrated Teaching of the same topics was done and Post test was taken (50 MCQs ).Comparison of pre and post test was done.

Results: The analysis was done by Microsoft Excel Programme.The results were expressed as Mean $\pm S D$. $P$ value $<0.05$ was considered statically significant. On comparing the mean marks of Pre test and Post test, we found that there was a significant increase in the marks scored in the Post test.

Likert Scale: On the basis of questionnaire for Likert Scale, majority of students fall in 2 categories: Neutral(72.9\%) and Agree(26\%).

Conclusion: By this study we conclude that integrated teaching should be included in medical curriculum and should be commenced from the beginning of the medical career of an individual.

Keywords: Integrated teaching, Likert Scale, Medical Curriculum, Pre-Test, Post-Test.
\end{abstract}

\section{Introduction}

Integration in education can be defined as coordination of different learning activities to ensure the harmonious functioning of educational process (1). There are many innovations and trends in medical education that have been undertaken globally which includes self directed learning, problem based learning, integrated teaching and community orientation(2). Integrated Teaching refers to a way of connecting skills and knowledge from multiple sources and experiences or applying skills and practice in various settings. It simply means bridging connection between academic knowledge and practicals (3). Integrated teaching offers many advantages (4) and may be a key factor in the delivery of an effective educational programme (5). An Integrated Curriculum refers to a non-compartmentalised approach to basic science learning, in which course of study is instead organised around organ systems like cardiovascular system, gastrointestinal system, respiratory system, etc(6). Medical education basically aims to produce medical personnel having sound clinical competences and community orientation with proficient communication skills. All these are very essential to solve formidable health problems (7). With the existing medical practices, there is general dissatisfaction. The reason for this is identified as the present day medical curricula (8).

Integrated teaching is an important strategy in medical education, but it is a complex concept(9). The need for greater integration of subjects in the medical curriculum has featured prominently in reports on medical education, including the GPEP(General Professional Education of the Physicians) report, "Educating Medical Students"(10).

There are 4 major components in integrated teaching: (11)

1. Integration of experience

2. Social integration

3. Integration of knowledge

4. Integration as a curriculum design

To improve the quality of students and to have effective diagnosis and better treatment of the patients, integrated learning is the need of hour. In the recent years, throughout the world such curricula has been used by faculties who teach the students(12-16). Integrated teaching \& learning approaches enable learning across multiple domains. So, Medical Council of India desires the incorporation of integration in the medical curriculum in order to provide the students with a holistic rather than fragmented learning process(17). 
Medical Educationist based aims to produce medical personnel having sound clinical competences and community orientation with proficient communication skills (18) and an integrated approach with strong clinical relevance captures student's attention and creates more excitement in learning(19).

\section{Aims And Objecives}

1. Introducti on of integrated teaching learning in First yr. MBBS students.

2. To study the impact and compare Integrated teaching learning method with traditional T-L method.

\section{Materials And Methods}

After the approval of IRB (Institutional Review Board, Govt. Medical College, Kota) was taken, the present study was carried out during the routine classes of Biochemistry of First yr. MBBS Batch 201415 at Govt. Medical College, Kota(Rajasthan). Duration of study was from March 2015 to August 2015. Following the consent of students, a batch of 148 students was included in the study. Sensitization of faculties of Anatomy and Physiology was done and traditional teaching was done on the topics Jaundice and Thyroid. Each topic was taught in 3 classes each. Pre test (50 MCQs of each topic) was taken. There was NO negative marking Integrated teaching was done on the topics Thyroid and Jaundice in 4 different sessions in Biochemistry Department with the help of HOD Anatomy and HOD Physiology, with the help Power point presentations. A post test (50 MCQs of each topic) taken. Comparison of results (Pre test and Post test) was done. There was NO negative marking The analysis was done by Microsoft Excel Programme. The results were expressed as Mean \pm SD. P value $<0.05$ was considered statistically significant. Likert scale was prepared by 5 questionnaire regarding integrated teaching and traditional teaching.

\section{Observation And Results}

Pretest on Thyroid and Jaundice was taken in form of 50 MCQ's for each topic. Each test was of 50 marks.As shown in TABLE 1, the mean marks of both the topics were calculated. Among the total of 148 students, $1(0.67 \%)$ student scored marks between 0-10, 85(57.4\%) scored marks between 1120 and 62(41.9\%) students scored marks between 21-30. There was no student falling in category of 31-40 and 41-50.Post test on Thyroid and Jaundice was taken in form of 50 MCQ's for each topic. Each test was of 50 marks.. The mean marks of both the topics were calculated. Among the total of 148 students, $1(0.67 \%)$ scored marks between 11-20, 108(72.9\%) students scored marks between 21-30 and $39(26 \%)$ students scored marks between 31-40. There was no student falling in category of $0-10$ and 41-50.

Table -1

\begin{tabular}{|l|l|l|}
\hline & PRETEST & POST TEST \\
\hline MARKS & NO. OF STUDENTS & NO. OF STUDENTS \\
\hline 0 to 10 & 01 & 0 \\
\hline 11 to 20 & 85 & 01 \\
\hline 21 to 30 & 62 & 108 \\
\hline 31 to 40 & 0 & 39 \\
\hline 41 to 50 & 0 & 0 \\
\hline
\end{tabular}

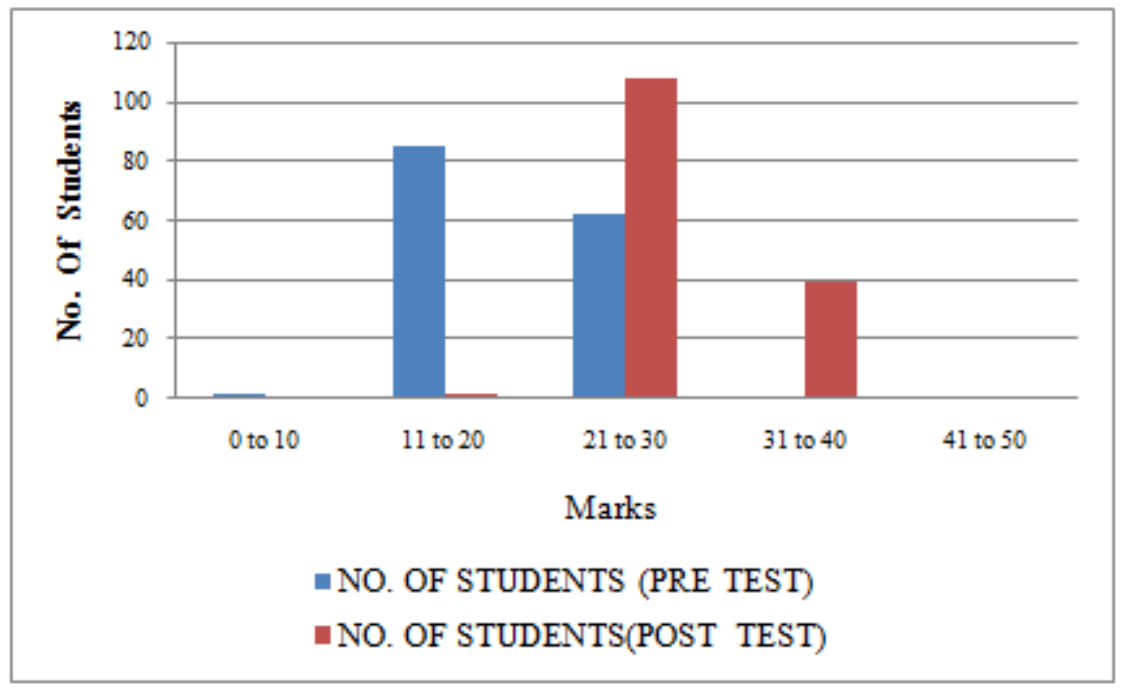

Graph -1: Shows The Comparison Of Number Of Students According To Marks In Pre And Post Test 


\section{Statistical Analysis}

The analysis was done by Microsoft Excel Programme.The continuous parameters were expressed as $\mathrm{MEAN} \pm \mathrm{SD}$. Student's unpaired $\mathrm{t}$ - test was applied to the data. $\mathrm{p}$ value $<0.05$ was considered statically significant.On comparing the mean marks of Pre test and Post test, we found that there was a significant increase in the marks scored in the Post test. The results are shown in Table 2.

Table 2 : Showing Mean \pm SD of Pre test and Post test. *p value $<0.05$ is significant.

\begin{tabular}{|l|l|l|l|}
\hline Parameter & $\begin{array}{l}\text { Pre Test } \\
(\mathrm{N}=148) \\
(\mathrm{Mean} \pm \mathrm{SD})\end{array}$ & $\begin{array}{l}\text { Post Test } \\
(\mathrm{N}=148) \\
(\text { Mean } \pm \mathrm{SD})\end{array}$ & P Value \\
\hline Marks & $19.87 \pm 3.75$ & $28.81 \pm 4.21$ & $<0.05^{*}$ \\
\hline
\end{tabular}

\section{Likert Scale}

Questionnaire

1. Did you find Integrated Teaching beneficial over Traditional ?

2. Was Integrated Teaching time consuming ?

3. Did topics covered had actual Integration?

4. Should Integrated Teaching be included in Medical curriculum?

5. For Clinical Knowledge, should Horizontal Teaching be included with Vertical Teaching ?

On the basis of questionnaire for Likert Scale, majority of students fall in 2 categories:

- $\quad \operatorname{Neutral}(72.9 \%)$

- $\quad$ Agree $(26 \%)$

Table-3: Showing the number of students falling in different categories on basis of questionnaire of likert scale.

\begin{tabular}{|l|l|l|l|l|l|}
\hline S.no & Strongly Agree & Agree & Neutral & DisAgree & Strongly DisAgree \\
\hline 1. & 00 & 45 & 101 & 02 & 00 \\
\hline 2. & 00 & 38 & 110 & 00 & 00 \\
\hline 3. & 00 & 50 & 97 & 1 & 00 \\
\hline 4. & 00 & 32 & 116 & 00 & 00 \\
\hline 5. & 00 & 32 & 116 & 00 & 00 \\
\hline
\end{tabular}

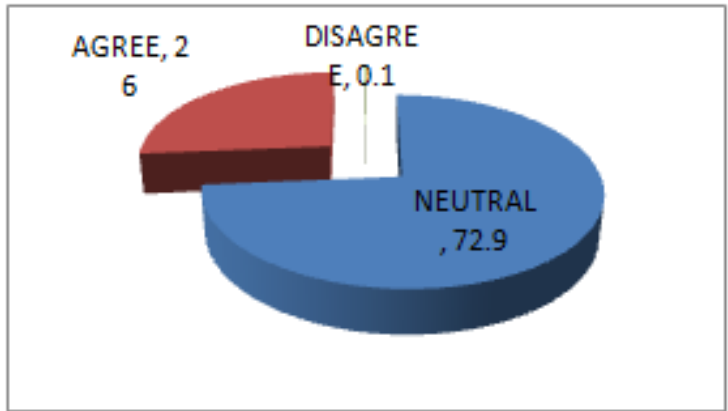

PIE DIAGRAM: Showing the percentage of students falling in different categories on basis of questionnaire of likert scale.

\section{Discussion And Conclusion}

The basic aim of medical education worldwide is to educate the students regarding health which is physical, mental, social and spiritual well being. Providing a vast information to the medical students in a planned, organized and integrated manner is the duty of the medical teachers, so that they get a better understanding of integration in the human body that no system functions in isolation but operates in an organized and interdependent manner to achieve optimum level of functioning. There are many advances in scientific knowledge with each year passing by.The innovative changes in medical education and growing minds of MBBS students. This necessitates constant school curriculum. These include self-directed learning, problem-based learning, IT and community orientation [20].

Thus, we the medical teachers share a great responsibility of implementing this project throughout India to provide the country "The Best Doctors" for the society. There is tremendous responsibility on the institutions providing medical education for bringing about required innovations in the existing system. This is to meet the defined needs of the societies [21]. The Medical council of India has stressed upon need-based curriculum, that should stimulate student's interest and inculcate drive to learn more. In our study, the results of the post-test showed that Integrated Teaching was found to be better than traditional teaching, which goes in favour with results of study done by Madhuri et al(2000), which also showed 
that results of post test (taken after integrated teaching)[22]. It enhances knowledge and the scope of medical education.This was an attempt to introduce horizontal integrated teaching learning method. Although the sensitization of students and faculty was difficult but they showed positive attitude towards this innovation in education. Significant results were obtained on comparing the results of traditional and integrated teaching. By this study we conclude that the time has come to bring a drastic change in the teaching methods. A proper motivation and extensive planning is needed in the field of medical education to change the approach of learning for the students. It may be included in medical curriculum.

\section{Limitation}

"No journey is complete without certain hurdles"Although the project started with planning, but as it progressed, I faced some limitations. The sensitization of students, faculty and time were most important issues which had to be dealt with. Due to lack of faculty members, there was a difficulty in implementing the project in its full bloom. Due to unequal time distribution among the departments of First MBBS, the classes were difficult to be coordinated in such a way that only few topics could be taught at a particular time.

\section{Acknowlegement}

Department of Anatomy, Physiology and Biochemistry, Govt. Medical College, Kota (Rajasthan), India Conflict Of Interest Declared: None

\section{References}

[1]. P.S. Bhuiyan, N.N. Rege, A.N. Supe: (second edition): The art of teaching medical students. Medical Education Technology Cell. Seth G.S. Medical College and K.E.M Hospital, Mumbai.305-312.

[2]. Smith S.R.( 2005). Toward an integrated medical curriculum. Medical Health R I,88(8):258-261.

[3]. Huber M.T, P. Hutchings;2004. Integrative learning: Mapping the Terrain. The Academy in Transition. Washington, DC: association of American Colleges and Universities.

[4]. Harden RM, Sowden Susette ,Dunn WR. Some Educational Strategies in Curriculum Development: The SPICES Model. ASME Medical Education Booklet Number 18. Med Educ 1984; 18:284-97.

[5]. Schmidt HG, Machiels-Bongaerts M, Hermans H, Tencate TJ, Venekamp R, Boschuizen HPA. The Development of Diagnostic Competence : Comparison of a problem - Based, an Integrated and a conventional Medical Curriculum. Acad Med 1996:71(6): 658-64.

[6]. Barzansky Barbara, Jonas Harry S, Etzel Syla I,(1989). Undergraduate Medical Education. JAMA,262(8):1018-9.

[7]. Paul V K.,(1993). Innovative Programmes Of Medical Education: Case studies. Indian J Pediatr, 60:759-68.

[8]. World Health Organization, (1981) Global strategy for Health for All by year 2000.Health for all series (No.3). World Health Organization: Geneva: 181:23.

[9]. Pring R., Curriculum Integration, P.265-272. In: Hooper R.ed. The Curriculum: Context Design and Development Education. Edinburgh: Oliver and Boyd, 1970

[10]. Association of American Medical Colleges. Physician for the $21^{\text {st }}$ Century:Report of the project panel of the General Professional Education of the Physicians and College Preparation for Medicine.J Med Edu 1984:59,Part 2:1-208.

[11]. Beane J.(1997). Curriculum integration Teachers College press, New York

[12]. Irby D.,L. Wilkerson (2003).Educational Innovation in Academic Medicine and Environmental Trends. J Gen Intern Med , $18 ; 370-6$.

[13]. Shimura T., T. Aramaki, K. Shimizu, T. Miyashita, K. Adachi, A. Teramoto.(2004). Implementation of Integrated medical curriculum in Japenese Medical Schools. J Nippon Med Sch,71:11-16.

[14]. Damegh,S.A.(2005). Comparison of an integrated problem based learning curriculum with the traditional discipline based curriculum in KSA.J Coll Phys Surg Pak, 15:605-8.

[15]. Ghosh, S., H.V. Pandya(2008). Implementation of Integrated Learning Programme in Neurosciences during First year of Traditional Medical Course Perception of Students And Faculty. BMC Med Edu, 8:44.

[16]. Vyas , R, M. Jacob, M.Faith, B. Issac , S. Rabi, S. Sathiskumar, D. Selvakumar,A. Ganesh(2008). An Effective Integrated Learning Programme in the First Year of Medical Learning Programme in the First year of Medical course. Natl Med $\mathbf{J}$ India, 21:21-6.

[17]. Arun V Jamkar, Vishwanath L Yemul and Gurpreet Singh :Integrated teaching program with student centered case base learning for undergraduates at B.J Medical College, Pune. www.faimer.org/education/fellows/abstracts/04 jamkar.pdf

[18]. Muller J.H., Jain S., Loeser H., Tebby D.M., (2008).Lersone learned about integrating a medical school curriculum: Perception of students, Faculty and curriculum leaders. Med Edu, 42:778-85.

[19]. Custer's E. J., Cate O.T., 2006. Medical student's attitudes towards and perception of the basic sciences: a comparison students in the old and the new curriculum at the university medical centre Ulrecht. The Netherland Med Edu, 36:1142-50.

[20]. Smith, S. R. (2005). Toward an Integrated Medical curriculum. Med Health R I, 88(8): 258-61.

[21]. The Edinburgh Declaration. (1988) World congress on the Medical Education of the world Federation of Medical Education. Med Edu 22: 481-2

[22]. Madhuri S , Ujjawala J, Avinash Supe, Y.A. Deshmukh. Introducing Integrated Teaching In Undergraduate Medical Curriculum. IJPSR Vol.(1), 2010, 18-22. 